\title{
Global and regional evolution of short-lived radiatively-active gases and aerosols in the Representative Concentration Pathways
}

\author{
Jean-François Lamarque • G. Page Kyle • \\ Malte Meinshausen • Keywan Riahi • Steven J. Smith • \\ Detlef P. van Vuuren • Andrew J. Conley • Francis Vitt
}

Received: 17 September 2010 /Accepted: 21 June 2011 /Published online: 5 August 2011

(C) Springer Science+Business Media B.V. 2011

\begin{abstract}
In this paper, we discuss the results of 2000-2100 simulations following the emissions associated with the Representative Concentration Pathways (RCPs) with a chemistry-climate model, focusing on the changes in 1) atmospheric composition (troposphere and stratosphere) and 2) associated environmental parameters (such as nitrogen deposition). In particular, we find that tropospheric ozone is projected to decrease (RCP2.6, RCP4.5 and RCP6) or increase (RCP8.5) between 2000 and 2100, with variations in methane a strong contributor to this spread. The associated tropospheric ozone global radiative forcing is shown to be in agreement with the estimate used in the RCPs, except for RCP8.5. Surface ozone in 2100 is projected to change little compared from its 2000 distribution, a much-reduced impact from previous projections based on the A2 highemission scenario. In addition, globally-averaged stratospheric ozone is projected to recover at or beyond pre-1980 levels. Anthropogenic aerosols are projected to strongly decrease in the 21 st century, a reflection of their projected decrease in emissions. Consequently, sulfate deposition is projected to strongly decrease. However, nitrogen deposition is projected to increase over certain regions because of the projected increase in $\mathrm{NH}_{3}$ emissions.
\end{abstract}

J.-F. Lamarque $(\bowtie) \cdot$ A. J. Conley $\cdot$ F. Vitt

National Center for Atmospheric Research, Boulder, USA

e-mail: lamar@ucar.edu

G. P. Kyle • S. J. Smith

Joint Global Change Research Institute, Pacific Northwest National Laboratory, College Park, MD, USA

M. Meinshausen

Earth System Analysis, Potsdam Institute for Climate Impact Research, Potsdam, Germany

K. Riahi

International Institute for Applied Systems Analysis, Laxenburg, Austria

D. P. van Vuuren

Netherlands Environmental Assessment Agency, Bilthoven, Utrecht, Netherlands

D. P. van Vuuren

Utrecht University, Utrecht, The Netherlands 


\section{Introduction}

In support of the analysis of future climate change (for instance as part of community efforts such as the CMIP5 exercise (Taylor et al. 2009)), a set of pathways has been generated to define a range of possible future atmospheric composition over the $21 \mathrm{st}$ century (van Vuuren et al. 2011a). These pathways, referred to as Representative Concentrations Pathways (RCPs) are derived from estimated emissions computed by a set of Integrated Assessment Models (Masui et al. 2011; Riahi et al. 2011; Thomson et al. 2011; van Vuuren et al. 2011b) and, for each of these pathways, a rich dataset of information regarding emissions, concentrations and land-use has been generated. For longlived greenhouse gases, these emissions have been converted into concentrations (and consequently radiative forcing estimates) using the Model for the Assessment of Greenhouse-gas Induced Climate Change (MAGICC, Meinshausen et al. 2011). However, because of regional variations in emissions, it is important to perform the calculation of the distribution of short-lived climate agents using a comprehensive three-dimensional chemistry-climate model. It is the results of such calculations that are discussed in this paper. As such, it is a follow-up to Lamarque et al. (2010), where, using the same model, historical emissions (1850-2000) are used and the corresponding computed changes in ozone and aerosols are discussed.

In addition to the changes in atmospheric composition mentioned above, emissions of shortlived gases and aerosols lead to deposition of nitrogen and sulfate compounds that affect the biosphere, on land and in the ocean (Billen et al. 2010; Butchart et al. 2010, and references therein). In particular, specific thresholds for nitrogen deposition above which additional input is detrimental to plants have been used to identify regions where past and future trends may have adverse impacts (Bobbink et al. 1998; Dentener et al. 2006a; Galloway et al. 2008). Conversely, nitrogen deposition may also influence the carbon cycle by stimulating plant growth (Schlesinger 2009). None of those feedbacks are included in our study or in the RCP projections. As such, it will be important to evaluate the response of the climate system (and how it affects radiative forcing estimates) in more comprehensive models with explicit representation of biogeochemistry and the carbon cycle.

The paper is organized as follows: in Section 2, we describe the model used for the chemistry simulations, along with the experimental design. In Section 3, we focus on the analysis of ozone changes, both tropospheric and stratospheric. Section 4 describes the simulated aerosol changes. In both Sections 3 and 4, radiative forcing calculations are included. We analyze nitrogen and sulfate deposition in Section 5. Discussion and conclusions are in Section 6.

\section{Model description and experimental design}

In order to provide the distributions of future aerosol loadings, deposition rates and ozone concentrations discussed later in this paper, we perform simulations with the same model setup as used for providing the respective historical datasets, as described in Lamarque et al. (2010). We use the global three-dimensional Community Atmosphere Model version 3.5 (Gent et al. 2009) modified to include interactive chemistry to calculate distributions of gases and aerosols in the troposphere and the lower to mid-stratosphere. In order to limit computational cost, this model only solves for the atmospheric and land portions of the climate system, using pre-computed sea-surface temperatures and sea-ice extent as boundary conditions. 
The model configuration used in this study includes a horizontal resolution of $1.9^{\circ}$ (latitude) by $2.5^{\circ}$ (longitude) and 26 hybrid levels, from the surface to $\approx 40 \mathrm{~km}$ with a timestep of $30 \mathrm{~min}$; the transient simulations were performed continuously between 2001 and 2100. In order to simulate the evolution of the atmospheric composition over the model vertical range, the chemical mechanism used in this study is formulated to provide an accurate representation of both tropospheric and stratospheric chemistry (Lamarque et al. 2008). Specifically, to successfully simulate the chemistry above $100 \mathrm{hPa}$, we include a representation of stratospheric chemistry (including polar ozone loss associated with stratospheric clouds) from version 3 of MOZART (MOZART-3; Kinnison et al. 2007). The tropospheric chemistry mechanism has a simplified representation of non-methane hydrocarbon chemistry in addition to standard methane chemistry, extended from Houweling et al. (1998) with the inclusion of isoprene and terpene oxidation and updated to JPL-2006 (Sander et al. 2006). This model has a representation of aerosols based on the work by Tie et al. $(2001,2005)$; i.e., sulfate aerosol is formed by the oxidation of $\mathrm{SO}_{2}$ in the gas phase (by reaction with the hydroxyl radical) and in the aqueous phase (by reaction with ozone and hydrogen peroxide). Furthermore, the model includes a representation of ammonium nitrate that is dependent on the amount of sulfate present in the air mass following the parameterization of gas/aerosol partitioning by Metzger et al. (2002). Because only the bulk mass is calculated, a lognormal distribution is assumed for all aerosols using different mean radius and geometric standard deviation (Liao et al. 2003). We use a 1.6 days of exponential lifetime for the conversion from hydrophobic to hydrophilic carbonaceous aerosols (organic and black). Natural aerosols (desert dust and sea salt) are implemented following Mahowald et al. (2006a and b), and the sources of these aerosols are derived based on the model-calculated wind speed and surface conditions.

For all the simulations, the initial conditions correspond to the distributions of all chemically active species from the January 12001 results of the transient simulation (18502000) described in Lamarque et al. (2010). For each RCP one simulation has been performed. Results are presented for all the RCPs: RCP2.6, also known as RCP3PD, RCP4.5, RCP6 and RCP8.5.

At the lower boundary, the time-varying (monthly values) zonal-averaged distributions of $\mathrm{CO}_{2}, \mathrm{CH}_{4}, \mathrm{H}_{2}, \mathrm{~N}_{2} \mathrm{O}$ and all the halocarbons (CFC-11, CFC-12, CFC-113, HCFC-22, $\mathrm{H}-1211, \mathrm{H}-1301, \mathrm{CCl}_{4}, \mathrm{CH}_{3} \mathrm{CCl}_{3}, \mathrm{CH}_{3} \mathrm{Cl}$ and $\mathrm{CH}_{3} \mathrm{Br}$ ) are specified following the datasets described in Meinshausen et al. (2011), except for $\mathrm{H}_{2}$ which is kept at a constant 500 ppbv. Emissions from anthropogenic activities and biomass burning (natural and anthropogenically-forced) are taken from the various RCPs. Note that the biomass burning emissions vary amongst RCPs and in time, following changes in land-use; however, no climate feedback with fire frequency is included. Finally, the natural emissions of ozone precursors and of sulfur compounds (from non-eruptive volcanoes, Dentener et al. 2006b) are kept constant (i.e. set at their value in 2000) for the whole duration of the simulations. While reasonable for the historical period (Lathière et al. 2006), this is an assumption that will need to be evaluated in future studies, especially for the case of biogenic volatile organic compounds (VOC) emissions, which can be climate and $\mathrm{CO}_{2}$-dependent (Guenther et al. 2006; Young et al. 2009).

As no climate model simulations forced by the RCPs were available at the time our simulations were performed, we have used previously generated monthly-mean timevarying sea-surface temperatures (SSTs) and sea-ice distributions using analogous (see Table 1) AR4 simulations by CCSM-3 (Meehl et al. 2007). The choice of the closest analogue to the Supplemental Report on Emission Scenarios (SRES)-based climate simulations is driven by its estimated total radiative forcing at 2100 (Meehl et al. 2007). 
Table 1 Specification of the AR4 simulations by CCSM3 (Meehl et al. 2007) used to obtain sea-surface temperatures necessary for the RCP simulations discussed in this paper. Radiative forcing from the SRES projections (W/m², second column) are estimated from Figure 9.13 in Ramaswamy et al. (2001)

RCP simulation

Scenario used in CCSM3 simulation

RCP2.6

Commitment

RCP4.5

B1 $\left(4.2 \mathrm{~W} / \mathrm{m}^{2}\right)$

RCP6

A1B $\left(6.1 \mathrm{~W} / \mathrm{m}^{2}\right)$

RCP8.5

A2 $\left(8.0 \mathrm{~W} / \mathrm{m}^{2}\right)$

Because of the proximity in overall radiative forcing between the RCPs and the SRES (Table 1), it can be expected that the projected climate used in our simulations will be within the range from intermodel differences and climate noise (as defined in section 9.2.2.1. of Ramaswamy et al. 2001) of the corresponding RCPs. Since the RCP-driven climate simulations are not available for analysis yet, the full analysis of this impact will need to be performed elsewhere.

While the simulations presented here cannot be fully representative of future climates under the RCPs, we provide some general description of the simulated changes as these will impact atmospheric chemistry. In particular, changes in temperature, water vapor and precipitation affect reaction and removal rates (Murazaki and Hess 2006). As found in the CCSM3 full climate model simulations (Meehl et al. 2007), the various projections lead to an increase in surface temperature (Fig. 1). Its latitudinal distribution (Fig. 2) indicates the well-documented polar amplification. In terms of humidity-based diagnostics (precipitation, total moisture in atmosphere and cloud cover), we find an overall increase during the $21 \mathrm{st}$ century, with RCP8.5 leading to the largest signal (Figs. 1 and 2), very similar in essence to the SRES-driven projections (Meehl et al. 2007).

The anthropogenic emissions used for the simulations described in this paper are listed in Table 2; they are described in more details in the various specific papers in this issue and evaluated in Granier et al. (2011). Except for $\mathrm{NH}_{3}$, global emissions of all ozone and aerosol precursors across all RCPs are projected to decrease by the end of the 21 st century. At the same time, regional trends strongly vary. There is also a peak value for most emissions around 2010-2030. Of all emissions presented in Table 2, sulfur emissions show the most rapid decrease, reaching less than a quarter of the 2000 estimates by the end of the 21 st century. Many of the other emissions are reduced by a factor of 2 over the same period.

\section{Ozone}

In this section, we discuss the results from the simulations described above and focus on the analysis of ozone (tropospheric and stratospheric), both on its distribution of ozone and its associated radiative forcing.

\subsection{Analysis of present-day distribution of tropospheric ozone}

Before estimating the changes in ozone between 2000 (or 1850) and 2100, we first evaluate the ozone distribution from the model results (5 year average, 2000 conditions) from the historical simulation (Lamarque et al. 2010) against available observations spanning the 

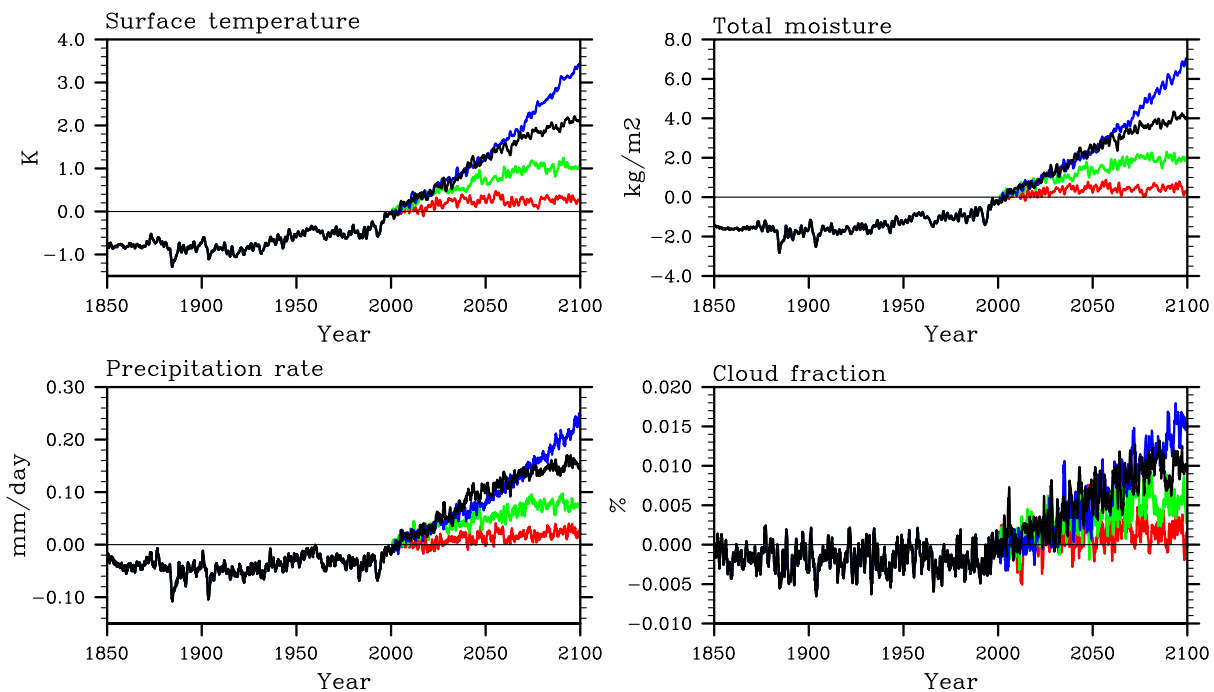

Fig. 1 Time evolution of annual mean globally-averaged surface temperature (upper left),. verticallyintegrated moisture content (upper right), total (convective and large-scale) precipitation (bottom left) and cloudiness (bottom right). All results shown as the departure from the 2000 mean. Red curve: RCP2.6. Green curve: RCP4.5. Black curve: RCP6. Blue curve: RCP8.5. Results for 1850-2000 are from Lamarque et al. (2010)

troposphere and lower stratosphere over the whole globe. Analysis of present-day surface and mid-troposphere ozone concentrations and recent trends are discussed in Lamarque et al. (2010). In particular, it is shown there that the present-day conditions are quite well reproduced; trends in the Northern mid-latitudes are somewhat underestimated, but other

Fig. 2 Zonal distribution of decadal average (2090-2099) of surface temperature and total precipitation. Red curve: RCP2.6. Green curve: RCP4.5. Black curve: RCP6. Blue curve: RCP8.5
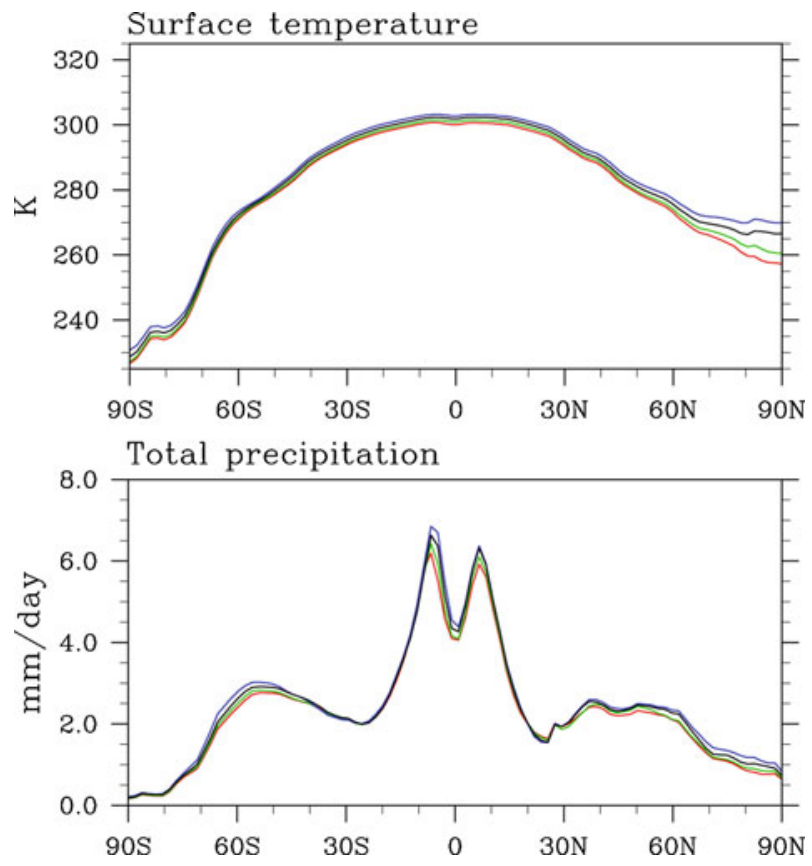
Table 2 Total (anthropogenic+shipping+aircraft+biomass burning) global emissions for ozone precursors and aerosols: $\operatorname{Tg}($ species $)$ /year, except $\mathrm{NO}_{\mathrm{x}}$ emissions expressed as $\operatorname{Tg}\left(\mathrm{NO}_{2}\right)$ /year

\begin{tabular}{|c|c|c|c|c|c|c|c|c|}
\hline & & 2000 & 2010 & 2020 & 2040 & 2060 & 2080 & 2100 \\
\hline \multirow[t]{4}{*}{$\mathrm{CO}$} & $\mathrm{RCP} 2.6$ & 1067.2 & 1028.8 & 982.5 & 878.1 & 779.2 & 663.7 & 607.8 \\
\hline & RCP4.5 & 1069.0 & 1061.8 & 1002.3 & 953.1 & 778.5 & 558.0 & 477.3 \\
\hline & RCP6 & 1068.8 & 1048.8 & 1028.3 & 1049.7 & 996.1 & 873.0 & 792.2 \\
\hline & RCP8.5 & 1069.4 & 1029.6 & 1052.0 & 951.2 & 841.1 & 757.2 & 690.3 \\
\hline \multirow[t]{4}{*}{$\mathrm{NO}_{\mathrm{x}}$} & RCP2.6 & 125.3 & 128.8 & 120.0 & 98.4 & 89.4 & 67.8 & 52.5 \\
\hline & RCP4.5 & 125.5 & 124.1 & 117.3 & 107.0 & 84.0 & 62.6 & 59.3 \\
\hline & RCP6 & 125.7 & 124.0 & 115.6 & 107.2 & 93.0 & 65.5 & 52.9 \\
\hline & RCP8.5 & 125.5 & 129.6 & 138.3 & 121.4 & 104.0 & 95.2 & 86.2 \\
\hline \multirow[t]{4}{*}{ NMVOC } & RCP2.6 & 210.5 & 216.2 & 212.6 & 192.0 & 166.4 & 138.6 & 125.5 \\
\hline & $\mathrm{RCP} 4.5$ & 210.8 & 211.7 & 196.0 & 202.3 & 179.9 & 150.3 & 140.0 \\
\hline & RCP6 & 210.8 & 213.3 & 212.0 & 221.8 & 214.1 & 191.8 & 172.1 \\
\hline & RCP8.5 & 210.8 & 214.6 & 224.4 & 217.9 & 201.2 & 188.6 & 176.2 \\
\hline \multirow[t]{4}{*}{$\mathrm{BC}$} & RCP2.6 & 7.8 & 8.8 & 8.5 & 5.7 & 4.4 & 3.7 & 3.4 \\
\hline & $\mathrm{RCP} 4.5$ & 7.8 & 8.1 & 7.8 & 6.8 & 5.5 & 4.1 & 3.9 \\
\hline & RCP6 & 7.8 & 8.1 & 7.7 & 7.4 & 6.5 & 5.1 & 4.4 \\
\hline & RCP8.5 & 7.8 & 7.8 & 7.5 & 6.1 & 5.2 & 4.7 & 4.2 \\
\hline \multirow[t]{4}{*}{ OC } & RCP2.6 & 35.9 & 37.6 & 37.6 & 32.3 & 29.7 & 26.9 & 25.3 \\
\hline & $\mathrm{RCP} 4.5$ & 35.9 & 34.7 & 30.5 & 27.9 & 24.9 & 20.4 & 19.4 \\
\hline & RCP6 & 35.9 & 37.1 & 36.8 & 36.7 & 35.7 & 33.3 & 32.2 \\
\hline & RCP8.5 & 36.0 & 34.9 & 34.1 & 31.4 & 28.4 & 26.4 & 23.9 \\
\hline \multirow[t]{4}{*}{$\mathrm{NH}_{3}$} & $\mathrm{RCP} 2.6$ & 48.0 & 52.7 & 57.7 & 64.7 & 71.1 & 77.0 & 81.6 \\
\hline & $\mathrm{RCP} 4.5$ & 48.5 & 51.3 & 52.6 & 56.3 & 55.8 & 53.6 & 52.9 \\
\hline & RCP6 & 48.6 & 53.3 & 52.1 & 60.8 & 69.0 & 73.9 & 74.9 \\
\hline & RCP8.5 & 48.6 & 52.7 & 58.8 & 67.8 & 73.7 & 77.5 & 81.6 \\
\hline \multirow[t]{4}{*}{$\mathrm{SO}_{2}$} & $\mathrm{RCP} 2.6$ & 107.5 & 107.9 & 85.6 & 39.3 & 27.4 & 19.5 & 12.9 \\
\hline & RCP4.5 & 107.8 & 111.9 & 102.9 & 69.6 & 41.4 & 25.5 & 22.5 \\
\hline & RCP6 & 107.7 & 107.4 & 95.1 & 83.3 & 69.8 & 30.0 & 21.9 \\
\hline & RCP8.5 & 107.7 & 101.5 & 96.1 & 65.6 & 45.4 & 36.9 & 25.7 \\
\hline
\end{tabular}

latitude bands are well captured. Here, we show (Fig. 3) a comparison for a set of ozonesonde stations results at $200 \mathrm{hPa}$ (i.e. in the upper troposphere and lower stratosphere, where most of the ozone radiative forcing of surface temperature resides (Lacis et al. 1990)). Most stations have a well-reproduced seasonal cycle, with a slight underestimate of springtime values in the tropical regions (stations Naha, Hilo and Natal), possibly due to too strong convective activity in the model (bringing low ozone from the surface into the upper troposphere) at that time of the year.

Overall, the evaluation (along with additional recent studies discussing and evaluating simulations performed with this model, e.g. Sanderson et al. 2008; Shindell et al. 2008; Anenberg et al. 2009; Fiore et al. 2009; Reidmiller et al. 2009; Jonson et al. 2010; Lamarque and Solomon 2010) indicates that the model is quite accurate in its representation of present-day ozone in the troposphere and lower stratosphere. Additional information on present-day and historical ozone trends can be found in Lamarque et al. (2010). 

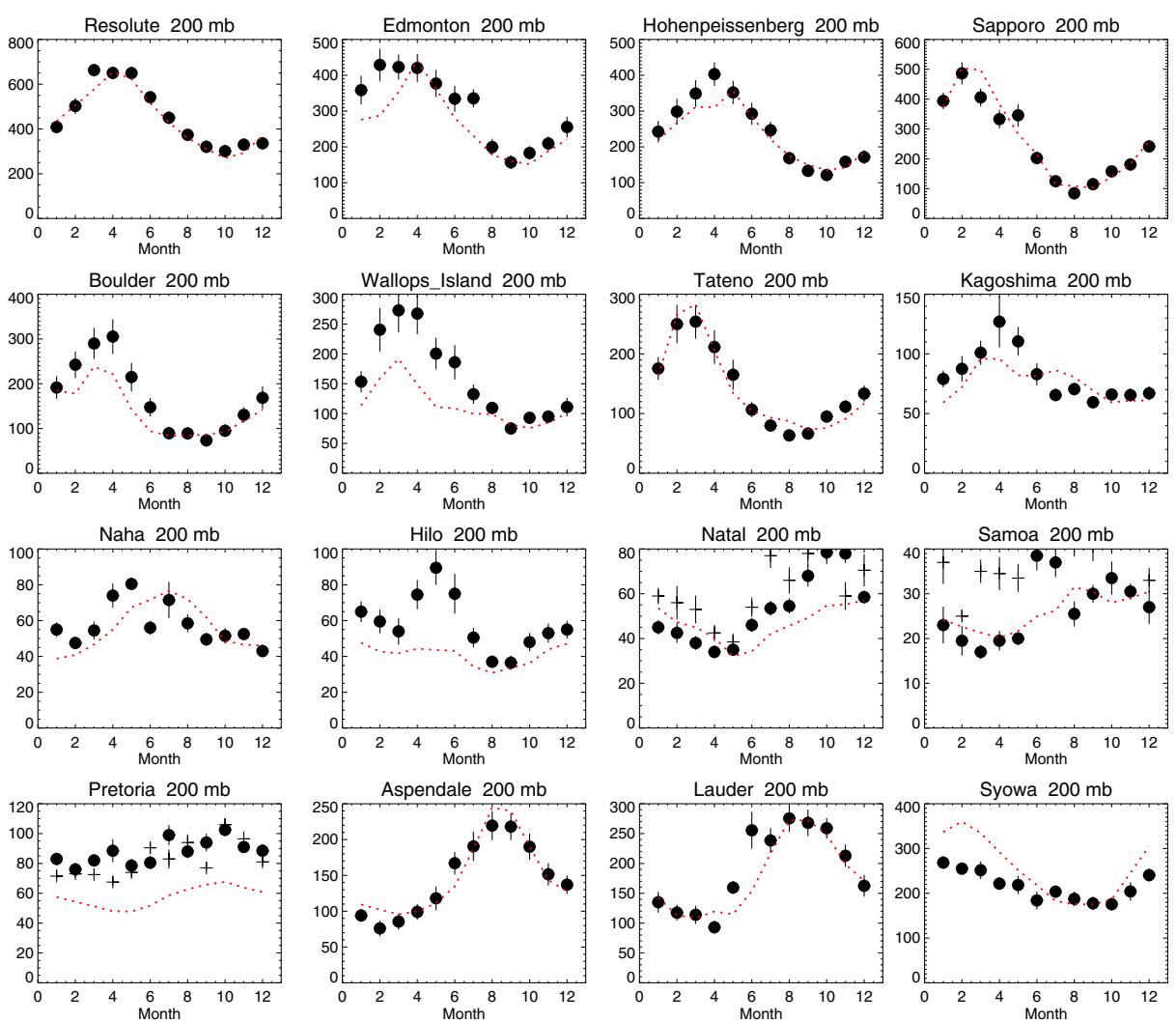

Fig. 3 Comparison of simulated present-day ozone (in ppbv) at $200 \mathrm{hPa}$ (upper troposphere/lower stratosphere) with the ozonesonde-based climatology of Logan (1999). Black dots are the observations, dashed line shows model results. The stations displayed a range of latitudes from Arctic (Resolute, top left) to Antarctica (Syowa, bottom right)

\subsection{Change in tropospheric ozone burden}

Integrated between the surface and $200 \mathrm{hPa}$ (i.e., integrated over the troposphere), the globally-averaged change between 1850 and 2100 for each RCP is shown in Fig. 4. The model simulates a historical change between 1850 and 2000 of $\approx 9$ Dobson Units (DU) comparable to the model-range (8.9-10.8 DU for chemistry-climate models with tropospheric and stratospheric chemistry) documented in Gauss et al. (2006). Beyond 2000 , tropospheric ozone is expected to increase over its 2000 level only in the case of RCP8.5, at least beyond 2050. The gobal emission totals of important ozone precursors $\left(\mathrm{NO}_{\mathrm{x}}, \mathrm{CO}, \mathrm{VOCs}\right.$ ) are not strikingly different between RCPs (except $\mathrm{NO}_{\mathrm{x}}$ for which the RCP8.5 emissions in 2100 are $\approx 30 \%$ larger than in the other RCPs); however, the methane emissions (and therefore concentrations) in RCP8.5 are significantly larger than in the other RCPs (van Vuuren et al. 2011a), leading to a tropospheric mixing ration ranging from 1,500 ppbv to 3,750 ppbv. Such difference amongst RCPs in methane mixing ratios will strongly impact tropospheric ozone, much more so than the difference in $\mathrm{NO}_{\mathrm{x}}$ emissions as summarized in Table 2 of Fiore et al. (2002). This is therefore the main driver behind the estimated tropospheric ozone change in the 21 st century. 


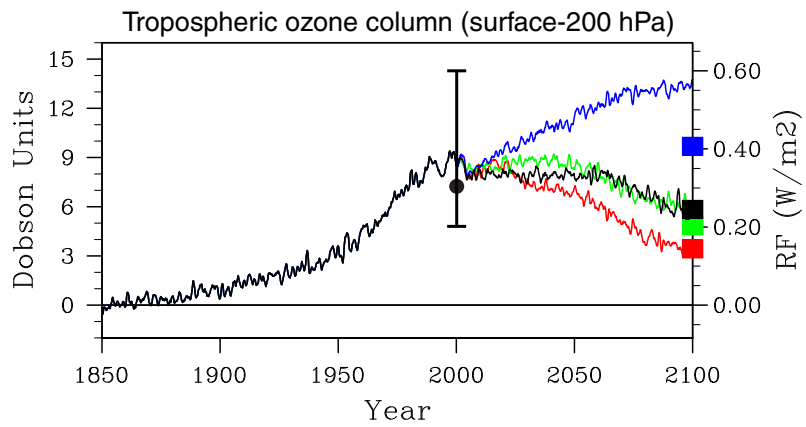

Fig. 4 Time evolution of the globally averaged tropospheric ozone column (and associated radiative forcing), shown as the departure from the 1850 mean. Red curve: RCP2.6. Green curve: RCP4.5. Black curve: RCP6. Blue curve: RCP8.5. Filled squares at year 2100 indicate the MAGICC estimated radiative forcing for each corresponding RCP. In addition, the AR4 mean and range estimates of the tropospheric ozone forcing are added (black line). Note that the AR4 and MAGICC estimates have been corrected by $0.05 \mathrm{~W} / \mathrm{m}^{2}$ to take into account the radiative forcing between 1750 and 1850

Using the scaling factor of $0.042 \mathrm{~W} / \mathrm{m}^{2} / \mathrm{DU}$ (Ramaswamy et al. 2001) to compute the ozone radiative forcing associated with the previously described change in tropospheric ozone, we find that our estimated globally- and annually-averaged radiative forcing between 1850 and 2000 is in good agreement with the IPCC-AR4 best estimate between 1750 and 2005 (Table 2.12 in Forster and Ramaswamy, 2007). To facilitate the comparison with our simulated change with respect to 1850 , we have corrected (in Fig. 4) the 1750 -referenced radiative forcing estimate by $-0.05 \mathrm{~W} / \mathrm{m}^{2}$, as calculated in Meinshausen et al. (2011). In the case of RCP8.5, the additional tropospheric ozone (between 2000 and 2100) is expected to increase the radiative forcing by an additional $0.2 \mathrm{~W} / \mathrm{m}^{2}$ by 2100 , while the other projections lead to a decrease in the radiative forcing of tropospheric ozone between 0.07 and $0.2 \mathrm{~W} / \mathrm{m}^{2}$. It is however clear that the radiative forcing by tropospheric ozone strongly varies regionally (Shindell et al. 2003) but this is not documented here.

It is worth noting that the estimated tropospheric ozone radiative forcing (and hence concentration perturbation) estimated in MAGICC for the RCP8.5 (and to a lower extent RCP4.5) case is noticeably lower than in our model simulations. This lower forcing is likely a combination of the limited applicability of the chemistry parameterizations (Prather and Ehhalt 2001) currently used in MAGICC and the lack of consideration of the increased flux

Fig. 5 Time evolution of the globally averaged stratospheric (above $200 \mathrm{hPa}$ ) ozone column, shown as the departure from the 1850 mean. Red curve: RCP2.6. Green curve: RCP4.5. Black curve: RCP6. Blue curve: RCP8.5. Results for 1850-2000 are from Lamarque et al. (2010)

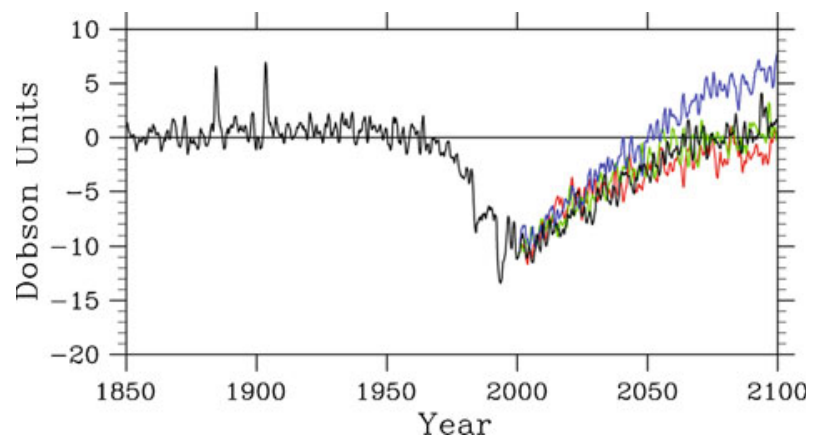


of ozone from the stratosphere to the troposphere (Stevenson et al. 2006; Hegglin and Shepherd 2009), a result of stratospheric ozone increase (Eyring et al. 2010a) and increased stratospheric circulation (Rind et al. 2001; Garcia et al. 2007; Lamarque et al. 2008) in relation to increasing greenhouse gases. A more detailed discussion is provided in the next section. It is however important to note that the overall uncertainty in tropospheric ozone forcing is rather large (Fig. 4).

\subsection{Change in stratospheric ozone burden}

As a smaller contributor to the overall radiative forcing of climate (Forster et al. 2007), stratospheric ozone is not as important on the global scale, at least in terms of radiative forcing. It is however important in the polar regions where the stratospheric ozone trends have been shown to impact the dynamical structure of the atmosphere (Thompson and Solomon 2002). The evaluation of our model in simulating recent stratospheric ozone is discussed in Austin et al. (2010) and Eyring et al. (2010a and b), with overall good performance, except for a smaller than observed ozone depletion in the Southern Hemisphere associated with too-warm simulated temperatures. All RCPs have similar emission and concentration trajectories for the ozone-depleting substances (except $\mathrm{N}_{2} \mathrm{O}$ ); everything else being equal, all RCPs will therefore provide similar ozone changes in the stratosphere. However, additional changes in stratospheric composition (and in this case, mostly $\mathrm{CO}_{2}$ as it is the largest contributor in terms of impact on stratospheric temperatures during the 21 st century) can affect the vertical circulation in the stratosphere, and consequently lead tochanges in the distribution of ozone (Rind et al. 2001; Butchart et al. 2006; Garcia et al. 2007). It can therefore be expected that stratospheric ozone will be different between the various RCPs. Indeed, as indicated in Fig. 5, the simulated 2100 stratospheric $(0-200 \mathrm{hPa})$ ozone in this model is expected to recover to at least pre-1950 levels in all cases. The RCP2.6, RCP4.5 and RCP6 simulations produce a 2100 stratospheric ozone recovery to pre-1950 levels while the RCP8.5 simulation produced 2100 stratospheric ozone levels higher than the pre-1950 (and even 1850) levels. As in the case of tropospheric ozone, the radiative forcing associated with RCP8.5 stratospheric ozone projection will lead to a quite different value than the MAGICC estimated value, which is only tied to the equivalent effective stratospheric chlorine (EESC) levels and do not take into account such chemistry-climate couplings.

\subsection{Change in zonally-averaged surface ozone}

Previously projected changes in surface ozone (Prather et al. 2003) under the A2x scenario have indicated annual mean changes between 2000 and 2100 of approximately $25 \mathrm{ppbv}$ in the Northern tropical to extra-tropical regions (with a maximum around $25^{\circ} \mathrm{N}$ ) and a minimum in the Southern hemisphere of $12 \mathrm{ppbv}$. The reduction in $\mathrm{NO}_{\mathrm{x}}$ emissions in RCP2.6, RCP4.5 and RCP6 (along with similar or decreasing methane concentrations) generate a reduction in surface ozone in 2100 compared to 2000 for those simulations (Fig. 6). In contrast, the RCP8.5 projection provides a slight increase of approximately 5 ppbv. This is much less than the corresponding value in Prather et al. (2003) for the A2 scenario, which had continually increasing $\mathrm{NO}_{\mathrm{x}}$ emissions through 2100 . The widespread distribution of the increase (along with the fact that even RCP8.5 has decreasing emissions for ozone precursors between 2000 and 2100) suggests that this is related to the aforementioned increase in methane (Fiore et al. 2002), but more analysis is needed to confirm this hypothesis. It will be important to identify if the much-reduced surface ozone 
Fig. 6 Latitudinal distribution of zonally-averaged surface ozone 2091-2100 minus 2000-2009.

Red curve: RCP2.6. Green curve: RCP4.5. Black curve: RCP6. Blue curve: RCP8.5

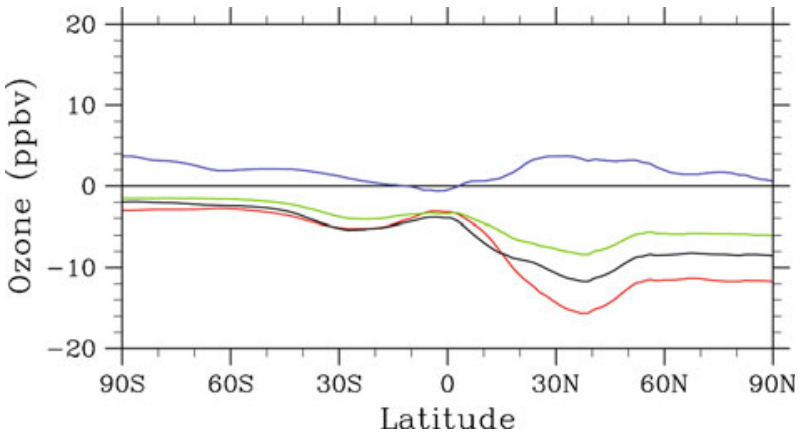

response (compared to A2 projections discussed in Prather et al. 2003) is a robust feature amongst a variety of models.

\section{Aerosols}

Aerosols are a strong component of the radiative forcing associated with anthropogenic emissions. This is achieved through a combination of direct radiative forcing and cloudaerosol interactions (indirect effects), as summarized in Forster et al. (2007). In the simulations discussed here, only the direct effects are considered. In the discussion of the results, we therefore focus on the evolution of the distribution of sulfate, black and organic carbon and ammonium nitrate aerosols. Our model consists of a bulk representation (Lamarque et al. 2005a), leading to an external mixing assumption for all radiative calculations. The importance of this latter assumption is discussed below.

\subsection{Comparison with present-day observations}

The main contributor (at the global scale) to aerosol radiative forcing between pre-industrial and 2000 is sulfate (Schulz et al. 2006). Comparison of simulated sulfate with 1990s observations from remote sites around the globe (Fig. 7) indicates that in many locations, the model is within a factor of 2 of the observations, except for a few stations in the tropical regions. In addition, the seasonal cycle (not shown) is also quite well reproduced at those stations, indicating an overall reasonable representation of present-day sulfate aerosols. Furthermore, comparison with the Interagency Monitoring of Protected Visual Environments (IMPROVE) network (Malm et al. 2004) indicate a satisfactory representation of surface sulfate over the United States in the late 1990s, and in particular over the polluted Northeast (Fig. 8). Analysis of the historical evolution of sulfate in Lamarque et al. (2010) also shows a reasonable comparison with respect to ice-core deposition observations over Greenland and overall agreement (burden and lifetime) with the multi-model results of Schulz et al. (2006).

In terms of the CAM-chem simulated aerosol optical depth (computed at $550 \mathrm{~nm}$, referenced hereafter as AOD), the annual global average (including natural and anthropogenic sources for all aerosols but ammonia) for present-day is 0.115 , in agreement with the satellite-based estimate (valid over the ocean) of $0.10-0.15$ by Mishchenko et al. (2007) but lower than recent satellite-based global estimates (Chung et al. 2005; Remer et al. 2008). Our present-day simulated value represents an increase of 0.0315 over the 1850 conditions $(0.08)$. This anthropogenic increase is very much in 


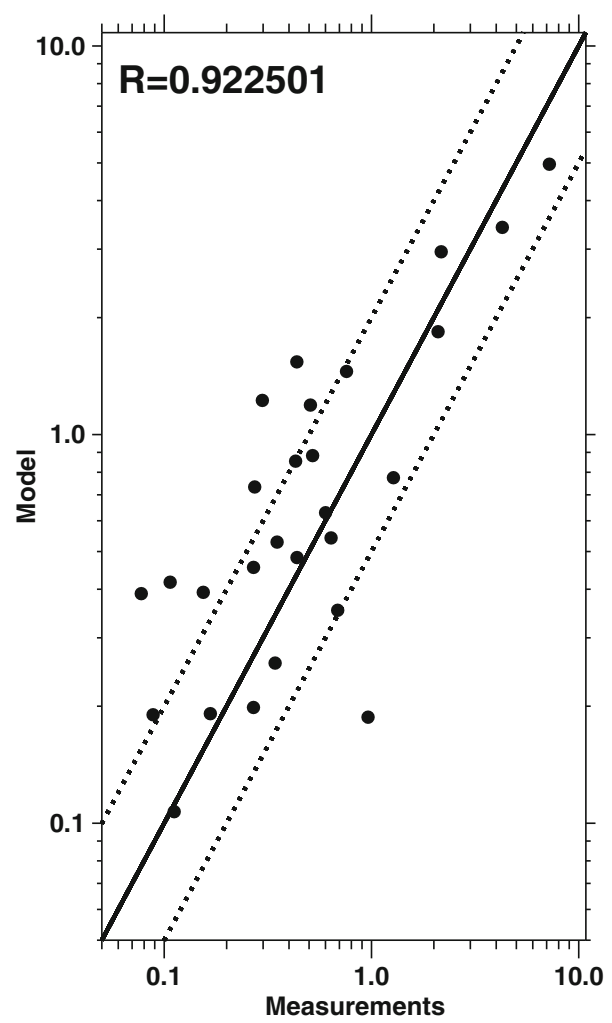

Fig. 7 Comparison of modeled and measured 1990s surface sulfate concentrations (in $\mu \mathrm{g} / \mathrm{m}^{3}$ ). Each dot represents a specific station (see Barth et al., 2000 and references therein), spanning the globe. All sites are sampling the remote regions

agreement with the average AeroCom results (Schulz et al. 2006). While the AeroCom reference point is 1750 instead of 1850 , the overall AOD associated with anthropogenic emissions in 1850 (and therefore the potential increases between 1750 and 1850) is, however, quite small in our simulation.

\subsection{Change in aerosol optical depth and burden}

Globally averaged, the simulated AOD after 2000 (Fig. 9) is decreasing similarly for all RCPs, following the strong decrease in anthropogenic emissions (van Vuuren et al. 2011a), especially for anthropogenic $\mathrm{SO}_{2}$ (decreases in black carbon and organic carbon anthropogenic emissions during the 21 st century are not quite as rapid). The projection in all RCPs is a drastic reduction in emissions from some previous 2100 estimates, such as the emissions based on the SRES A2 scenario (as discussed in Adams et al. (2001)). This is especially true for sulfate and the carbonaceous aerosols. This difference is not as large for ammonia emissions, although the RCP emissions (see Table 2) are lower than the value used in the A2 estimate $(88.8 \mathrm{Tg}(\mathrm{N}) /$ year, 2100 anthropogenic emissions only, as defined in Adams et al. (2001)). While the ammonia emissions are increasing in all RCPs, the simulated global burden of ammonium aerosols in 2100 is in the range $0.37-$ $0.48 \mathrm{Tg}\left(\mathrm{NH}_{4}\right)$, a decrease from the present-day value of 0.55 (in very good agreement 


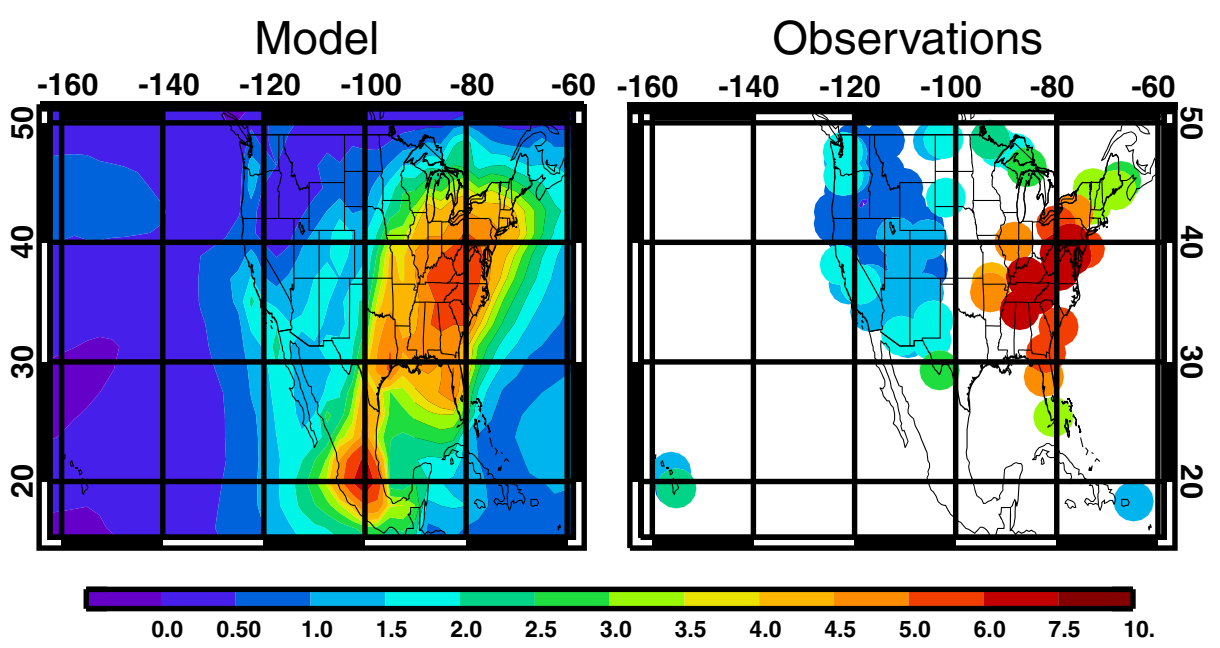

Fig. 8 Comparison of modeled and measured surface sulfate concentrations (in $\mu \mathrm{g} / \mathrm{m}^{3}$ ). Each dot represents a specific station over the IMPROVE network (Malm et al. 2004). See text for details

with the present-day estimate in Adams et al. 2001). This decrease is associated with the lower $\mathrm{NO}_{\mathrm{x}}$ emissions, leading to a slower conversion to ammonium nitrate. It is important to remember that this result might depend very much on the details of the aerosol equilibrium calculation (Metzger et al. 2002), and therefore could be modeldependent.

\subsection{Direct radiative forcing estimates}

Using the CCSM4 radiative transfer model (see description and references in http://www. ccsm.ucar.edu/models/ccsm4.0/cam/), we compute as a measure of radiative forcing the clear-sky change in shortwave radiation at the top of the atmosphere associated with a specific change in aerosol amount. In particular, this approach is directly comparable with the results from the AeroCom model intercomparison (Schulz et al. 2006). In all cases discussed below, the radiative forcing calculation is performed by computing the net shortwave flux at the top of the atmosphere using the same conditions (temperature, water vapor, surface conditions, long-lived greenhouse gases, ozone and aerosols) except for the specific aerosol considered (see Table 3); in summary, we perform two radiative transfer calculations, one with the 1850 specific aerosol distributions and one with the 2000

Fig. 9 Time evolution of globally-averaged aerosol optical depth at $550 \mathrm{~nm}$ annual 1850 2100. Red curve: RCP2.6. Green curve: RCP4.5. Black curve: RCP6. Blue curve: RCP8.5. Results for 1850-2000 are from Lamarque et al. (2010)

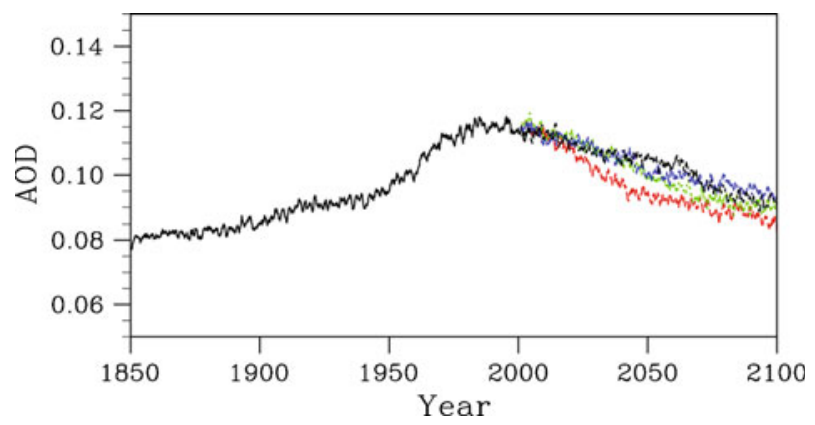


distribution of the same aerosol type (e.g. black carbon for example), with surface conditions, temperature and other state variables held fixed at the unperturbed values. The global annual average of the difference of these calculations defines the radiative forcing since 1850. Note that the calculations are performed under the assumption of external mixing of aerosols. The significance of this assumption is discussed below.

Our estimate of the clear-sky direct radiative forcing from aerosols in year 2000 ($0.8 \mathrm{~W} / \mathrm{m}^{2}$, with respect to 1850 ) is similar to the multi-model mean of the AeroCom models $(-0.68 \pm 0.28)$ in Schulz et al. (2006). Also, the black carbon radiative forcing computed here for year $2000\left(0.1 \mathrm{~W} / \mathrm{m}^{2}\right)$ is very comparable to the AeroCom results for fossil-fuel black carbon (i.e., the portion that significantly changed over the historical period, Schulz et al. 2006), which averaged $0.12 \pm 0.04 \mathrm{~W} / \mathrm{m}^{2}$. It is however on the low end of published estimates (e.g.. Chung and Seinfeld 2005; Bond et al. 2010; Jacobson 2010 and references therein); furthermore, many models are biased low against observations (Koch et al. 2009). It is however important to note that, following Cooke et al. (1999), the Optical Properties of Aerosols and Clouds (OPAC) optics for soot aerosols are used for black carbon. OPAC treats soot as hydrophobic, so that its optic properties are not affected by ambient humidity (Collins et al. 2002). This will lead to an underestimate of the soot radiative forcing. Furthermore, as discussed in Jacobson (2000, 2001) and Chung and Seinfeld (2005), the external mixture assumption will also lead to an underestimate of the overall radiative forcing of black carbon. It will therefore be important to estimate the black carbon radiative forcing in another aerosol model where internal mixture and/or hygroscopicity are considered.

Using the same methodology, we find that, in all cases, the RCP-projected direct radiative effect of aerosols in 2100 (Table 3) is considerably reduced from the 2000 estimates, in agreement with the evolution of their emissions. It is interesting to note that the relative role of ammonium nitrate, especially under the RCP2.6 projection (and to a lesser extent RCP8.5) becomes significantly larger than for the historical period, emphasizing the importance of performing chemistry simulations with adequate representation of the sulfate-dependent ammonium nitrate as described by Adams et al. (2001), Schaap et al. (2004) and Myhre et al. (2006).

\subsection{Change in the regional distribution of aerosols}

In this section, we discuss the change over time of the latitudinal distribution of the zonallyaveraged aerosol burden. This is illustrated in Fig. 10 with black carbon and sulfate total columns. We see that there is a shift in the 21 st century towards more tropical regions than during the 20th century, where the Northern mid-latitudes dominated the signal. It is particularly striking that the projections for black carbon emphasize the growth (followed by a slow decline in the second part of the century) over Africa (near the Equator) in all

Table 3 Clear sky radiative forcing $\left(\mathrm{W} / \mathrm{m}^{2}\right)$ with respect to 1850 . See text for details

\begin{tabular}{lccccc}
\hline & 2000 & 2100 RCP2.6 & 2100 RCP4.5 & 2100 RCP6 & 2100 RCP8.5 \\
\hline Black carbon & 0.10 & 0.01 & 0.02 & 0.03 & 0.04 \\
Organic carbon & -0.05 & -0.02 & 0.00 & -0.04 & -0.02 \\
Ammon. nitrate & -0.05 & -0.10 & -0.05 & -0.07 & -0.10 \\
Sulfate & -0.81 & -0.13 & -0.21 & -0.22 & -0.29 \\
Total & -0.81 & -0.24 & -0.24 & -0.36 & -0.37 \\
\hline
\end{tabular}



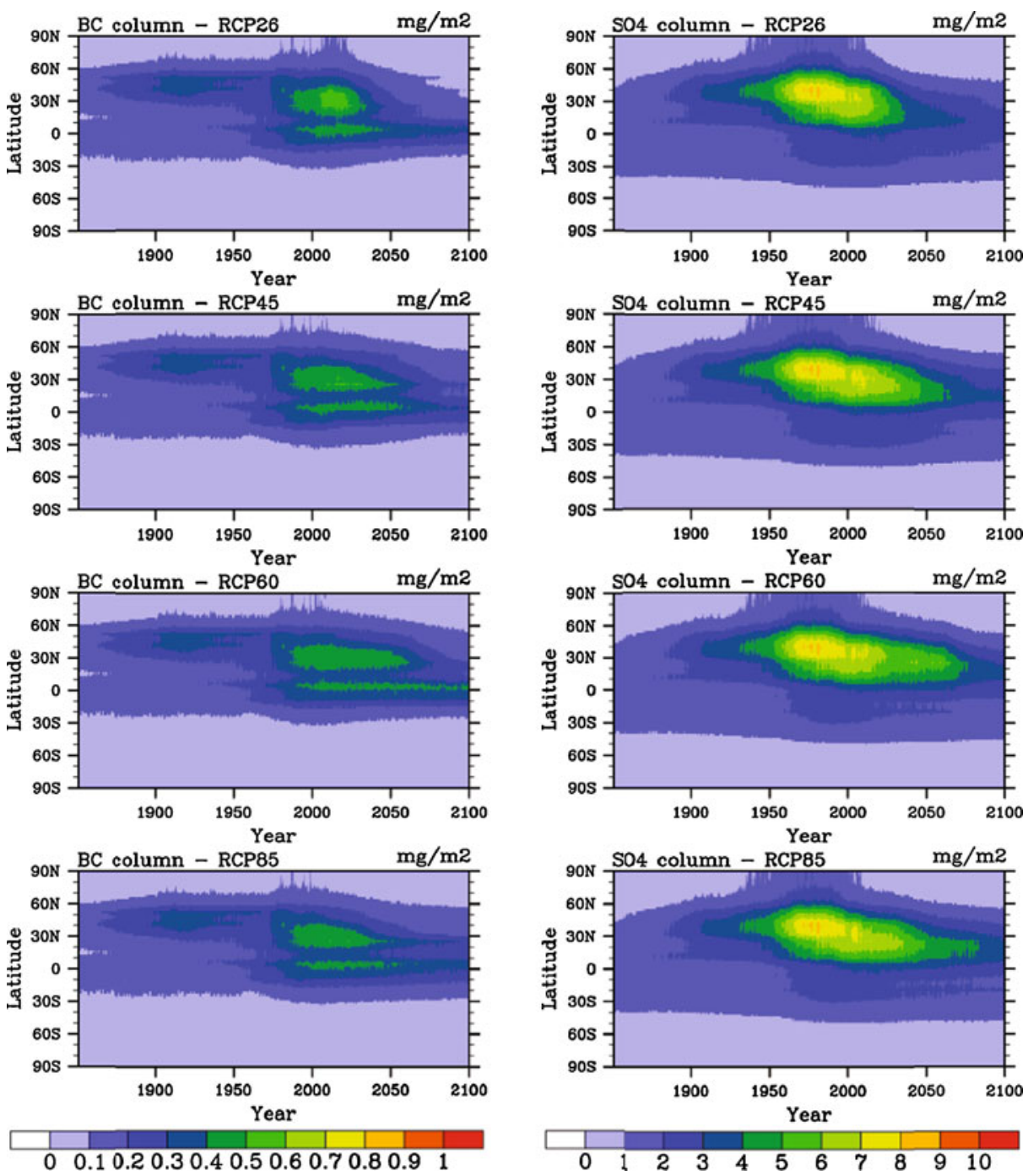

Fig. 10 Time evolution of column-integrated, zonally-averaged annual amount of black carbon (left) and sulfate (right) 1850-2100. Results for 1850-2000 are from Lamarque et al. (2010). Note different scale for each column

RCPs. On the other hand, the sulfate signal, when present, is limited to the latitudinal bands poleward of $15^{\circ} \mathrm{N}$, emphasizing the role of Asian emissions. Overall, in the Northern midlatitudes, the aerosol conditions at the end of the 21 st century are projected to be similar to those in the $1950 \mathrm{~s}$.

\section{Nitrogen and sulfate deposition}

Reactive nitrogen, from natural and anthropogenic emissions of nitrogen oxides and ammonia, is deposited over land and ocean through a variety of processes (namely, wet and 
dry deposition) such that it can potentially act as a fertilizer, with an impact on vegetation in non-agricultural areas (Holland et al. 1997; Bouwman et al. 2002; Holland et al., 2005; Lamarque et al. 2005b; Dentener et al. 2006a; Thornton et al. 2007; Reay et al. 2008). Everything else being equal, these additional $\mathrm{N}$ inputs into ecosystems can potentially lead to an increased carbon sink (Reay et al. 2008). Sulfate deposition, on the other hand, has been linked to a decrease in tree growth as a result of acidification (Savva and Berninger 2010).

We focus here on the analysis on land. For that purpose, we display in Table 4 the equivalent to Table 2 (simulation S1) of Dentener et al. (2006a); our table shows the average nitrogen deposition rate over specific region (see their definition at http://www.pbl. $\mathrm{nl} /$ en/themasites/image/background/regions/index.html). A very good agreement is found between our estimate and the multi-model mean from Dentener et al. (2006a), with maximum values over $1,000 \mathrm{mg}(\mathrm{N}) / \mathrm{m}^{2} /$ year (a threshold for plant sustainability, as described in Bobbink et al. 1998; Dentener et al. 2006a) situated mostly over Eastern Europe and South and East Asia, reflecting patterns in regional and upwind emissions (Lamarque et al. 2005b).

In addition, we show in Table 5 the projected evolution of nitrogen deposition (only the total $\mathrm{NO}_{\mathrm{y}}+\mathrm{NH}_{\mathrm{x}}$ is listed) to 2100 . We find that many regions (in bold) are projected to

Table 4 Nitrogen deposition for present-day conditions: $\mathrm{mg}(\mathrm{N}) / \mathrm{m}^{2} /$ year

\begin{tabular}{|c|c|c|c|c|c|c|}
\hline \multirow{2}{*}{$\begin{array}{l}\text { Nitrogen deposition } 2000 \\
\text { Region }\end{array}$} & \multicolumn{3}{|c|}{ All land $(\mathrm{mg}(\mathrm{N}) / \mathrm{m} 2 /$ year $)$} & \multicolumn{3}{|c|}{ Natural vegetation $(\mathrm{mg}(\mathrm{N}) / \mathrm{m} 2 /$ year) } \\
\hline & NOy & NHx & Total & NOy & NHx & Total \\
\hline Canada & 108.95 & 94.91 & 203.85 & 123.47 & 95.57 & 219.05 \\
\hline USA & 328.53 & 249.49 & 578.02 & 313.64 & 209.74 & 523.38 \\
\hline Mexico & 214.35 & 214.30 & 428.65 & 222.30 & 211.36 & 433.66 \\
\hline C. America & 117.68 & 97.29 & 214.97 & 115.95 & 92.86 & 208.82 \\
\hline Brazil & 117.38 & 259.87 & 377.25 & 117.32 & 252.03 & 369.35 \\
\hline Rest of S. Amer. & 96.74 & 179.42 & 276.15 & 103.94 & 198.96 & 302.90 \\
\hline N. Africa & 95.64 & 50.01 & 145.65 & 196.37 & 125.13 & 321.51 \\
\hline W. Africa & 215.19 & 204.32 & 419.51 & 291.41 & 293.37 & 584.78 \\
\hline E. Africa & 164.30 & 170.68 & 334.98 & 186.80 & 218.46 & 405.26 \\
\hline S. Africa & 160.71 & 154.47 & 315.18 & 168.64 & 166.45 & 335.09 \\
\hline W. Europe & 330.22 & 466.61 & 796.82 & 324.37 & 419.53 & 743.89 \\
\hline C. Europe & 500.35 & 569.02 & 1069.37 & 484.00 & 538.28 & 1022.29 \\
\hline Turkey & 300.74 & 415.59 & 716.33 & 298.62 & 401.56 & 700.17 \\
\hline Ukraine & 457.01 & 429.52 & 886.53 & 456.47 & 423.59 & 880.06 \\
\hline Kazakhstan area & 162.23 & 96.82 & 259.05 & 175.06 & 112.20 & 287.26 \\
\hline Russia & 154.17 & 170.18 & 324.35 & 139.79 & 168.96 & 308.75 \\
\hline Middle East & 167.73 & 84.37 & 252.10 & 205.96 & 127.75 & 333.71 \\
\hline South Asia & 334.44 & 686.76 & 1021.21 & 349.51 & 680.44 & 1029.95 \\
\hline Korea region & 573.90 & 469.84 & 1043.74 & 570.56 & 465.41 & 1035.97 \\
\hline East Asia & 365.79 & 617.20 & 982.99 & 427.86 & 700.39 & 1128.25 \\
\hline Southeast Asia & 250.08 & 385.22 & 635.30 & 245.43 & 377.20 & 622.63 \\
\hline Indonesia & 169.61 & 746.11 & 915.72 & 155.26 & 695.13 & 850.39 \\
\hline Japan & 397.71 & 284.83 & 682.53 & 396.48 & 283.30 & 679.77 \\
\hline Oceania & 57.76 & 68.58 & 126.35 & 58.10 & 66.79 & 124.90 \\
\hline Greenland & 22.14 & 9.53 & 31.68 & 28.61 & 12.30 & 40.91 \\
\hline
\end{tabular}


Table 5 Nitrogen deposition: $\mathrm{mg}(\mathrm{N}) / \mathrm{m}^{2} /$ year. Bold indicates increase between 2000 and 2100

\begin{tabular}{|c|c|c|c|c|c|}
\hline & 2000 & RCP2.6 2100 & RCP4.5 2100 & RCP6 2100 & RCP8.5 2100 \\
\hline Canada & 203.85 & 141.13 & 137.63 & 172.87 & 194.49 \\
\hline USA & 578.02 & 446.66 & 441.58 & 438.26 & 612.83 \\
\hline Mexico & 428.65 & 543.73 & 381.65 & 418.15 & 592.31 \\
\hline C. America & 214.97 & 318.33 & 218.42 & 287.59 & 277.41 \\
\hline Brazil & 377.25 & 464.68 & 315.65 & 481.35 & $\mathbf{5 5 5 . 8 5}$ \\
\hline Rest of S. Amer. & 276.15 & 407.72 & 266.26 & 405.47 & 412.57 \\
\hline N. Africa & 145.65 & 123.24 & 116.37 & 156.86 & 193.05 \\
\hline W. Africa & 419.51 & $\mathbf{5 7 5 . 1 4}$ & 460.10 & $\mathbf{5 3 5 . 8 1}$ & 640.15 \\
\hline E. Africa & 334.98 & 547.05 & 393.98 & 497.43 & 690.00 \\
\hline S. Africa & 315.18 & 445.68 & 265.85 & 358.93 & 536.28 \\
\hline W. Europe & 796.82 & 498.70 & 530.31 & 961.26 & 750.74 \\
\hline C. Europe & $1,069.37$ & 784.16 & 641.84 & $1,063.87$ & $1,524.25$ \\
\hline Turkey & 716.33 & 627.02 & 638.63 & 744.70 & 725.73 \\
\hline Ukraine & 886.53 & 683.33 & 436.92 & 800.88 & $1,296.48$ \\
\hline Kazakhstan area & 259.05 & 369.39 & 179.50 & 184.61 & 298.50 \\
\hline Russia & 324.35 & 225.96 & 199.69 & 233.75 & 345.72 \\
\hline Middle East & 252.10 & 294.48 & 201.71 & 286.31 & 403.22 \\
\hline South Asia & $1,021.21$ & $2,189.30$ & $1,414.41$ & 1,531.02 & $1,750.92$ \\
\hline Korea region & $1,043.74$ & $1,080.09$ & 865.16 & 941.03 & $1,009.24$ \\
\hline East Asia & 982.99 & $1,341.66$ & 889.06 & 1219.83 & $1,094.84$ \\
\hline Southeast Asia & 635.30 & 910.77 & 582.23 & 601.82 & 823.77 \\
\hline Indonesia & 915.72 & 990.67 & 305.86 & $1,011.67$ & 537.69 \\
\hline Japan & 682.53 & 444.00 & 406.94 & 511.41 & 745.57 \\
\hline Oceania & 126.35 & 144.46 & 125.82 & 139.80 & 165.77 \\
\hline Greenland & 31.68 & 11.81 & 16.92 & 15.33 & 25.26 \\
\hline
\end{tabular}

experience an increase in nitrogen deposition by the end of the 21 st century under the RCP2.6 and RCP8.5, mostly related to the projected changes in $\mathrm{NH}_{3}$ emissions (related to agricultural activities). Some regional average deposition rates are, based on our single model projection, reaching values above $2,000 \mathrm{mg}(\mathrm{N}) / \mathrm{m}^{2} /$ year, comparable to rates of net $\mathrm{N}$ mineralization for some ecosystems (Schlesinger 1997) .

Similarly, as can be expected from the large decrease in anthropogenic emissions of $\mathrm{SO}_{2}$, sulfur deposition rates (Table 6) are projected to be much lower than in 2000 for all regions. Note that our simulated rates of year 2000 sulfur deposition are in good agreement with the results of Dentener et al. (2006a). Note that the existence of significant deposition rates at all times over a limited number of regions (such as Japan) is a reflection of the inclusion of natural sources of sulfur compounds such as volcanoes (Dentener et al. 2006b).

\section{Discussion and conclusions}

We have presented and analyzed results from a set of simulation with a comprehensive three-dimensional chemistry-climate model. These simulations focused on the representation of short-lived radiative forcing agents (aerosols and gases) following the emissions 
Table 6 Sulfur deposition: $\mathrm{mg}(\mathrm{S}) / \mathrm{m}^{2} /$ year

\begin{tabular}{lrrrrr}
\hline & 2000 & 2100 RCP2.6 & 2100 RCP4.5 & 2100 RCP6 & 2100 RCP8.5 \\
\hline Canada & 155.5 & 20.7 & 31.3 & 24.6 & 34.1 \\
USA & 473.2 & 36.9 & 63.0 & 40.2 & 51.6 \\
Mexico & 421.5 & 65.4 & 114.0 & 64.4 & 82.9 \\
C. America & 185.0 & 88.5 & 105.2 & 89.8 & 80.9 \\
Brazil & 113.5 & 47.7 & 63.2 & 57.1 & 65.9 \\
Rest of S. Amer. & 150.9 & 84.9 & 94.9 & 109.1 & 108.4 \\
N. Africa & 106.3 & 28.7 & 73.4 & 52.6 & 45.3 \\
W. Africa & 135.8 & 101.9 & 110.4 & 78.8 & 120.2 \\
E. Africa & 133.8 & 67.3 & 88.2 & 65.7 & 94.7 \\
S. Africa & 145.9 & 159.7 & 77.7 & 58.8 & 122.3 \\
W. Europe & 480.3 & 72.3 & 113.5 & 83.0 & 82.8 \\
C. Europe & 993.8 & 93.7 & 164.8 & 112.3 & 109.3 \\
Turkey & 684.0 & 128.0 & 181.6 & 106.4 & 117.4 \\
Ukraine & 823.3 & 69.7 & 131.1 & 87.9 & 91.1 \\
Kazakhstan area & 241.7 & 31.1 & 51.5 & 43.3 & 86.0 \\
Russia & 212.1 & 34.8 & 45.4 & 42.6 & 55.2 \\
Middle East & 269.7 & 39.6 & 64.7 & 78.9 & 138.4 \\
South Asia & 415.8 & 75.3 & 157.0 & 255.4 & 292.7 \\
Korea region & $1,164.9$ & 223.3 & 247.0 & 278.9 & 279.2 \\
East Asia & 669.9 & 68.2 & 93.3 & 167.2 & 113.6 \\
Southeast Asia & 363.9 & 111.4 & 123.7 & 219.2 & 158.7 \\
Indonesia & 389.2 & 291.3 & 247.9 & 326.4 & 244.6 \\
Japan & $1,024.3$ & 531.6 & 541.5 & 564.8 & 564.5 \\
Oceania & 117.6 & 54.3 & 76.5 & 60.8 & 62.7 \\
Greenland & 34.9 & 10.9 & 12.3 & 11.5 & 13.1 \\
\hline & & & & &
\end{tabular}

from the recently developed Representative Concentration Pathways (RCPs). These projections will be used in a number of research activities that will be assessed in the Intergovernmental Panel on Climate Change (IPCC) 5th Assessment Report.

Using a set of observations representative of present-day conditions, we have shown that the model forced by the 2000 emissions provides a reasonable representation of atmospheric composition. In addition, we have shown that the model response to the 20th century emissions (Lamarque et al. 2010) is in agreement with previously published estimates of ozone and aerosol radiative forcings (except for a low black carbon radiative forcing); note that this can of course only ensure consistency with previous studies and may not reflect the real value of the specific quantity discussed. Based on this positive evaluation, we have documented and discussed projections for ozone (tropospheric and stratospheric), tropospheric aerosols and deposition (nitrogen and sulfate). In particular, we have shown that the tropospheric ozone radiative forcing by 2100 will vary strongly between RCPs, a consequence of the variations in precursor emissions and methane concentrations (Meinshausen et al. 2011). In that calculation, we have also shown that the tropospheric ozone radiative forcing estimate from MAGICC is underestimated for RCP8.5, most likely from a lack of representation of the stratospheric circulation changes under a high- $\mathrm{CO}_{2}$ scenario. The projections of aerosol loading are quite similar amongst RCPs, 
except for $\mathrm{NH}_{3}$, which acquires in RCP2.6 and RCP8.5 a relatively more prominent role, especially with respect to nitrogen deposition. Projected nitrogen deposition in RCP2.6 and RCP8.5 shows increase in a number of regions around the globe. It is however important to note that these estimates could be very model-dependent due to the inherent difficulties in modeling ammonia chemistry (this system is quite sensitive to the ratio of sulfate and ammonium/ammonia, with ammonium nitrate formation promoted when all sulfate is neutralized) and its deposition, mostly through precipitation processes.

Contrary to projections under the SRES A2x scenario (Prather et al. 2003), the emissions provided by the RCPs lead to surface ozone projections for 2100 that signal improvements over present-day conditions. In particular, at least in a zonal-average sense, surface ozone is projected to worsen little, if not improve, over the 2000 conditions, even in the RCP8.5 projection. It is clear however that more analysis of the specific conditions under which highpollution events occur is needed to fully identify the projected pollution regimes in 2100 .

Beyond the points mentioned above, the application of the RCP emissions as discussed in this paper have by design (e.g., use of prescribed sea-surface temperatures or $\mathrm{CO}_{2}$ and $\mathrm{CH}_{4}$ concentrations) or by lack of process representation (e.g. carbon cycle or wetland emissions) ignored some potentially strong feedbacks between various portions of the Earth system. In particular, the importance of considering SRES-generated sea-surface temperatures remains to be discussed. Similarly, the RCP emission projections provide a new paradigm under which existing simple estimating formulas (such as in MAGICC) for concentrations and/or radiative forcings likely need to be revisited.

Acknowledgments The authors would like to thank the three anonymous reviewers, P. Hess and E. Holland for their constructive feedback on previous versions of this paper. A. J. C. and F. V. were funded by the Department of Energy under the SciDAC program. Computing resources were provided by the Climate Simulation Laboratory at NCAR's Computational and Information Systems Laboratory (CISL), sponsored by the National Science Foundation and other agencies. This research was enabled by CISL compute and storage resources. Bluefire, a 4,064-processor IBM Power6 resource with a peak of 77 TeraFLOPS provided more than 7.5 million computing hours, the GLADE high-speed disk resources provided 0.4 PetaBytes of dedicated disk and CISL's 12-PB HPSS archive provided over 1 PetaByte of storage in support of this research project. The CESM project is supported by the National Science Foundation and the Office of Science (BER) of the U.S. Department of Energy. The National Center for Atmospheric Research is operated by the University Corporation for Atmospheric Research under sponsorship of the National Science Foundation.

\section{References}

Adams P, Seinfeld J, Koch D, Mickley L, Jacob D (2001) General circulation model assessment of direct radiative forcing by the sulfate-nitrate-ammonium-water inorganic aerosol system. J Geophys Res 106:1097-1111

Anenberg SC, West JJ, Fiore AM, Jaffe DA, Prather MJ, Bergmann D, Cuvelier C, Dentener FJ, Duncan BN, Gauss M, Hess P, Jonson JE, Lupu A, MacKenzie IA, Marmer E, Park RJ, Sanderson M, Schultz M, Shindell DT, Szopa S, Garcia Vivanco M, Wild O, Zeng G (2009) Intercontinenal impacts of ozone pollution on human mortality. Environ Sci Tech 43(17):6482-6487

Austin J, Struthers H, Scinocca J, Plummer D, Akiyoshi H, Baumgaertner AJG, Bekki S, Bodeker GE, Braesicke P, Bruhl C, Butchart N, Chipperfield M, Cugnet D, Dameris M, Dhomse S, Frith S, Garny H, Gettelman A, Hardiman S, Jockel P, Kinnison D, Lamarque J-F, Marchand M, Michou M, Morgenstern O, Nakamura T, Nielsen JE, Pitari G, Pyle J, Shepherd TG, Shibata K, Smale D, Stolarski R, Teyssedre H, Yamashita Y (2010) Chemistry climate model simulations of the Antarctic ozone hole. J Geophys Res, 115, D00M11, doi:10.1029/2009JD013577

Barth M, Rasch PJ, Kiehl JT, Benkovitz CM, Schwartz SE (2000) Sulfur chemistry in the NCAR CCM: description, evaluation, features and sensitivity to aqueous chemistry. J Geophys Res 105:1387-1415 
Billen G, Beusen A, Bouwman L, Garnier J (2010) Anthropogenic nitrogen autotrophy and heterotrophy of the world's watersheds: Past, present, and future trends, Global Biogeochem Cycles 24, GB0A11, doi:10.1029/2009GB003702.

Bobbink R, Hornung M, Roelofs JM (1998) The effects of airborne pollutants on species diversity in natural and semi-natural European vegetation. J Ecol 86:717-738. doi:10.1029/2002JD002272

Bond TC, Zarzycki C, Flanner MG, Koch DM (2010) Quantifying immediate radiative forcing by black carbon and organic matter with the Specific Forcing Pulse. Atmos Chem Phys Discuss 10:15713-15753

Bouwman AF, Van Vuuren DP, Derwent RG, Posch M (2002) A global analysis of acidification and eutrophication of terrestrial ecosystems. Water Air Soil Pollut 141:349-382

Butchart $\mathrm{N}$ et al (2006) Simulations of the anthropogenic change in the strength of the Brewer-Dobson circulation. Clim Dyn 27:727-741. doi:10.1007/s00382-006-0162-4

Butchart SHM et al (2010) Did we meet the 2010 biodiversity target? A synthesis of global indicators. Science 328(5982):1164-1168. doi:10.1126/science.1187512

Chung SH, Seinfeld JH (2005) Climate response of direct radiative forcing of anthropogenic black carbon. J Geophys Res 110:D11102. doi:10.1029/2004JD005441

Chung CE, Ramanathan V, Kim D, Podgorny IA (2005) Global anthropogenic aerosol direct forcing derived from satellite and ground-based observations. J Geophys Res 110:D24207. doi:10.1029/ 2005JD006356

Collins WD, Rasch PJ, Eaton BE, Fillmore DW, Kiehl JT, Beck CT, Zender CS (2002) Simulation of aerosol distributions and radiative forcing for INDOEX: Regional climate impacts, J Geophys Res, 107(D19), 8028, doi:10.1029/2000JD000032

Cooke WF, Liousse C, Cachier H, Feichter J (1999) Construction of a 1 degrees x 1 degrees fossil fuel emission data set for carbonaceous aerosol and implementation and radiative impact in the ECHAM4 model, J Geophys Res 104, 22, 137-22, 162

Dentener F et al (2006a) Nitrogen and Sulphur Deposition on regional and global scales: a multi-model evaluation, Global Biogeochem. Cycles, 20, GB4003, doi:10.1029/2005GB002672

Dentener F, Kinne S, Bond T, Boucher O, Cofala J, Generoso S, Ginoux P, Gong S, Hoelzemann JJ, Ito A, Marelli L, Penner JE, Putaud J-P, Textor C, Schulz M, van der Werf GR, Wilson J (2006b) Emissions of primary aerosol and precursor gases in the years 2000 and 1750 prescribed data-sets for AeroCom. Atmos Chem Phys 6:4321-4344

Eyring V et al (2010a) Sensitivity of 21st century stratospheric ozone to greenhouse gas scenarios. Geophys Res Lett 37:L16807. doi:10.1029/2010GL044443

Eyring V et al (2010b) Multi-model assessment of ozone return dates and ozone recovery in CCMVal-2 models. Atmos Chem Phys 10:9451-9472. doi:10.5194/acp-10-9451-2010

Fiore AM et al (2002) Linking ozone air pollution and climate change: the case for controlling methane. Geophys Res Lett 29:1919. doi:10.1029/2002GL015601

Fiore AM et al (2009) Multi-model estimates of intercontinental source-receptor relationships for ozone pollution. J Geophys Res 114:D04301. doi:10.1029/2008jd010816

Forster P, Ramaswamy V, Artaxo P, Berntsen T, Betts R, Fahey DW, Haywood J, Lean J, Lowe DC, Myhre G, Nganga J, Prinn R, Raga G, Schulz M, Van Dorland R (2007) Changes in atmospheric constituents and in radiative forcing. In: Solomon S, Qin D, Manning M, Chen Z, Marquis M, Averyt KB, Tignor M, Miller HL (eds) Climate change 2007: the physical science basis. contribution of working group $i$ to the fourth assessment report of the intergovernmental panel on climate change. Cambridge University Press, Cambridge

Galloway JN et al (2008) Transformation of the nitrogen cycle: recent trends, Questions, and Potential Solutions. Science 320:889. doi:10.1126/science.1136674

Garcia RR, Marsh DR, Kinnison DE, Boville BA, Sassi F (2007) Simulation of secular trends in the middle atmosphere, 1950-2003. J Geophys Res 112. doi:10.1029/2006JD007485

Gauss M et al (2006) Radiative forcing since preindustrial times due to ozone change in the troposphere and the lower stratosphere. Atmos Chem Phys 6:575-599

Gent PR, Yeager SG, Neale RB, Levis S, Bailey DA (2009) Improvements in a half degree atmosphere/land version of the CCSM. Clim Dynam 79:25-58. doi:10.1007/s00382-009-0614-8

Granier C, Bessagnet B, Bond T, D’Angiola A, van der Gon HG, Frost G, Heil A, Kainuma M, Kaiser J, Kinne $\mathrm{S}$ et al (2011) Evolution of anthropogenic and biomass burning emissions at global and regional scales during the 1980-2010 period. Climatic Change (this issue). doi:10.1007/s10584-011-0154-1

Guenther A, Karl T, Harley P, Wiedinmyer C, Palmer PI, Geron C (2006) Estimates of global terrestrial isoprene emissions using MEGAN (Model of Emissions of Gases and Aerosols from Nature). Atmos Chem Phys 6:3181-3210

Hegglin MA, Shepherd TG (2009) Large climate-induced changes in ultraviolet index and stratosphere-totroposphere ozone flux. Nat Geosci 2:687-691. doi:10.1038/ngeo604 
Holland EA et al (1997) Variations in the predicted spatial distribution of atmospheric nitrogen deposition and their impact on carbon uptake by terrestrial ecosystems, J Geophys Res, 102, 15,849-15,866

Holland EA, Braswell BH, Sulzman J, Lamarque J-F (2005) Nitrogen deposition onto the United States and Western Europe: synthesis of observations and models. Ecol Appl 15(1):38-57

Houweling S, Dentener F, Lelieveld J (2005) The impact of non-methane hydrocarbon compounds on tropospheric photochemistry. J Geophys Res 103, 10,673-10,696, doi:10.1029/97JD03582

Jacobson MZ (2000) A physically-based treatment of elemental carbon optics: implications for global direct forcing of aerosols. Geophys Res Lett 27:217-220

Jacobson MZ (2001) Strong radiative heating due to the mixing state of black carbon in atmospheric aerosols. Nature 409:695-697. doi:10.1038/35055518

Jacobson MZ (2010) Short-term effects of controlling fossil fuel soot, biofuel soot and gases, and methane on climate, Arctic ice, and air pollution health. J Geophys Res 115:D14209. doi:10.1029/ 2009JD013795

Jonson JE, Stohl A, Fiore AM, Hess P, Szopa S, Wild O, Zeng G, Dentener FJ, Lupu A, Schultz MG, Duncan BN, Sudo K, Wind P, Schulz M, Marmer E, Cuvelier C, Keating T, Zuber A, Valdebenito A, Dorokhov V, De Backer H, Davies J, Chen GH, Johnson B, Tarasick DW (2010) A multi-model analysis of vertical ozone profiles. Atmos Chem Phys 10:5759-5783

Kinnison DE, Brasseur GP, Walters S et al (2007) Sensitivity of chemical tracers to meteorological parameters in the MOZART-3 chemical transport model. J Geophys Res 112:D20302. doi:10.1029/2006JD007879

Koch D et al (2009) Evaluation of black carbon estimations in global aerosol models. Atmos Chem Phys 9:9001-9026

Lacis AA, Wuebbles DJ, Logan JA (1990) Radiative forcing of climate by changes in the vertical distribution of ozone. J Geophys Res 95:9971-9981

Lamarque J-F, Solomon S (2010) Impact of changes in climate and halocarbons on recent lower stratosphere ozone and temperature trends. J Clim 23:2599-2611. doi:10.1175/2010JCLI3179.1

Lamarque J-F, Kiehl JT, Hess PG, Collins WD, Emmons LK, Ginoux P, Luo C, Tie XX (2005a) Response of a coupled chemistry-climate model to changes in aerosol emissions: Global impact on the hydrological cycle and the tropospheric burdens of $\mathrm{OH}$, ozone and $\mathrm{NO}_{\mathrm{x}}$. Geophys Res Lett 32(16):L16809

Lamarque J-F, Kiehl J, Brasseur G, Butler T, Cameron-Smith P, Collins WD, Collins WJ, Granier C, Hauglustaine D, Hess P, Holland E, Horowitz L, Lawrence M, McKenna D, Merilees P, Prather M, Rasch P, Rotman D, Shindell D, Thornton P (2005b) Assessing future nitrogen deposition and carbon cycle feedback using a multi-model approach. Analysis of nitrogen deposition. J Geophys Res 110:D19303. doi:10.1029/2005JD005825

Lamarque J-F, Kinnison DE, Hess PG, Vitt F (2008) Simulated lower stratospheric trends between 1970 and 2005: identifying the role of climate and composition changes. J Geophys Res 113:D12301. doi:10.1029/2007JD009277

Lamarque J-F, Bond TC, Eyring V, Granier C, Heil A, Klimont Z, Lee D, Liousse C, Mieville A, Owen B, Schultz MG, Shindell D, Smith SJ, Stehfest E, Van Aardenne J, Cooper OR, Kainuma M, Mahowald N, McConnell JR, Naik V, Riahi K, van Vuuren DP (2010) Historical (1850-2000) gridded anthropogenic and biomass burning emissions of reactive gases and aerosols: methodology and application. Atmos Chem Phys 10. doi:10.5194/acp-10-7017-2010, 7017-7039

Lathière J, Hauglustaine DA, Friend AD, De Noblet-Ducoudré N, Viovy N, Folberth GA (2006) Impact of climate variability and land use changes on global biogenic volatile organic compound emissions. Atmos Chem Phys 6:2129-2146

Liao H, Adams PJ, Ching SH et al (2003) Interactions between tropospheric chemistry and aerosols in a unified general circulation model, J Geophys Res 108(D1), 4001, doi:10.1029/2001JD001260

Mahowald N, Muhs DR, Levis S et al (2006a) Change in atmospheric mineral aerosols in response to climate: last glacial period, pre-industrial, modern and doubled-carbon dioxide climates. J Geophys Res 111:D10202. doi:10210.11029/12005JD006653

Mahowald N, Lamarque J-F, Tie XX, Wolff E (2006b) Sea salt aerosol response to climate change: last glacial maximum, pre-industrial, and doubled-carbon dioxide climates. J Geophys Res 111:D05303. doi:10.1029/2005JD006459

Malm WC, Schichtel BA, Pitchford ML, Ashbaugh LL, Eldred RA (2004) Spatial and monthly trends in speciated fine particle concentration in the United States. J Geophys Res 109. doi:10.1029/ 2003JD003739

Masui T, Matsumoto K, Hijioka Y, Kinoshita T, Nozawa T, Ishiwatari S, Kato E, Shukla PR, Yamagata Y, Kainuma M (2011) A emission pathway to stabilize at $6 \mathrm{~W} / \mathrm{m} 2$ of radiative forcing (this issue). doi:10.1007/s10584-011-0150-5

Meehl GA, Stocker TF, Collins WD, Friedlingstein P, Gaye AT, Gregory JM, Kitoh A, Knutti R, Murphy JM, Noda A, Raper SCB, Watterson IG, Weaver AJ, Zhao Z-C (2007) Global Climate Projections. 
In: Solomon S, Qin D, Manning M, Chen Z, Marquis M, Averyt KB, Tignor M, Miller HL (eds) Climate change 2007: the physical science basis. Contribution of working group I to the fourth assessment report of the intergovernmental panel on climate change. Cambridge University Press, Cambridge

Meinshausen M, Smith SJ, Calvin K, Daniel JS, Kainuma MLT, Lamarque J-F, Matsumoto K, Montzka SA, Raper S, Riahi K et al (2011) The RCP greenhouse gas concentrations and their extensions from 1765 to 2300. Climatic Change (this issue). doi:10.1007/s10584-011-0156-z

Metzger S, Dentener F, Pandis S, Lelieveld J (2002) Gas/aerosol partitioning: 1. A computationally efficient model. J Geophys Res 107:D16. doi:10.1029/2001JD001102

Mishchenko MI et al (2007) Long-term satellite record reveals likely recent aerosol trend. Science 315:1543

Murazaki K, Hess P (2006) How does climate change contribute to surface ozone change over the United States? J Geophys Res 111. doi:10.1029/2005JD005873

Myhre G, Grini A, Metzger S (2006) Modelling of nitrate and ammonium-containing aerosols in presence of sea salt. Atmos Chem Phys 6:4809-4821. doi:10.5194/acp-6-4809-2006

Prather MJ, Ehhalt D (2001) Atmospheric chemistry and greenhouse gases. In: Houghton JT, Ding Y, Griggs DJ et al (eds) Climate change 2001: the scientific basis. Cambridge University Press, Cambridge, pp 239-287

Prather MJ et al (2003) Fresh air in the 21st century? Geophys Res Lett 30:1100-1103. doi:10.1029/ 2002GL016285

Ramaswamy V, Boucher O, Haigh J, Hauglustaine D, Haywood J, Myhre G, Nakajima T, Shi GY, Solomon S (2001) Radiative forcing of climate change. In: Houghton JT, Ding Y, Griggs DJ, Noguer M, van der Linden PJ, Dai X, Maskell K, Johnson CA (eds) Climate change 2001: The scientific basis, contribution of working group $\mathrm{I}$ to the third assessment report of the Intergovernmental Panel on Climate Change (IPCC). Cambridge University Press, Cambridge, United Kingdom, p 881

Reay DS, Dentener F, Smith P, Grace J, Feely RA (2008) Global nitrogen deposition and carbon sinks. Nature Geosci 1:430-437

Reidmiller DR, Fiore AM, Jaffe DA, Bergmann D, Cuvelier C, Dentener FJ, Duncan BN, Folberth G, Gauss M, Gong S, Hess P, Jonson JE, Keating T, Lupu A, Marmer E, Park R, Schultz MG, Shindell DT, Szopa S, Vivanco MG, Wild O, Zuber A (2009) The influence of foreign vs. North American emissions on surface ozone in the US. Atmos Chem Phys 9:5027-5042

Remer LA et al (2008) Global aerosol climatology from the MODIS satellite sensors, J Geophys Res 113 , D14S07, doi:10.1029/2007JD009661

Riahi K, Krey V, Rao S, Chirkov V, Fischer G, Kolp P, Kindermann G, Nakicenovic N, Rafai P (2011) RCP8.5: exploring the consequence of high emission trajectories. Climatic Change (this issue). doi:10.1007/ s10584-011-0149-y

Rind D, Lerner J, McLinden C (2001) Changes of tracer distribution in the doubled $\mathrm{CO}_{2}$ climate. J Geophys Res 106, 28,061-28,079

Sander SP et al (2006) Chemical kinetics and photochemical data for use in atmospheric studies evaluation number 15, Publication 06-2. Jet Propulsion Laboratory, Pasadena

Sanderson MG, Dentener FJ, Fiore AM, Cuvelier C, Keating TJ, Zuber A, Atherton CS, Bergmann DJ, Diehl T, Doherty RM, Duncan BN, Hess P, Horowitz LW, Jacob DJ, Jonson J-E, Kaminski JW, Lupu A, MacKenzie IA, Mancini E, Marmer E, Park R, Pitari G, Prather MJ, Pringle KJ, Schroeder S, Schultz MG, Shindell DT, Szopa S, Wild O, Wind P (2008) A multi-model study of the hemispheric transport and deposition of oxidised nitrogen. Geophys Res Lett 35:L17815. doi:10.1029/ 2008GL035389

Savva Y, Berninger F (2010) Sulphur deposition causes a large-scale growth decline in boreal forests in Eurasia, Global Biogeochem. Cycles, 24, GB3002, doi:10.1029/2009GB003749

Schaap M, van Loon M, ten Brink HM, Dentener FJ, Builtjes PJH (2004) Secondary inorganic aerosol simulations for Europe with special attention to nitrate. Atmos Chem Phys 4:857-874

Schlesinger WH (1997) Biogeochemistry, an analysis of global change. Academic Press

Schlesinger WH (2009) On the fate of anthropogenic nitrogen. Proceedings of the National Academy of Sciences 106:203-208. doi:10.1073/pnas.0810193105

Schulz M, Textor C, Kinne S, Balkanski Y, Bauer S, Berntsen T, Berglen T, Boucher O, Dentener F, Guibert S, Isaksen ISA, Iversen T, Koch D, Kirkevåg A, Liu X, Montanaro V, Myhre G, Penner JE, Pitari G, Reddy S, Seland Ø, Stier P, Takemura T (2006) Radiative forcing by aerosols as derived from the AeroCom present-day and pre-industrial simulations. Atmos Chem Phys 6:5225-5246

Shindell DT, Faluvegi G, Bell N (2003) Preindustrial-to-present-day radiative forcing by tropospheric ozone from improved simulations with the GISS chemistry-climate GCM. Atmos Chem Phys 3:1675-1702. doi:10.5194/acp-3-1675-2003 
Shindell DT, Teich H, Chin M, Dentener F, Doherty RM, Faluvegi G, Fiore AM, Hess P, Koch DM, MacKenzie IA, Sanderson MG, Schultz MG, Schulz M, Stevenson DS, Teich H, Textor C, Wild O, Bergmann DJ, Bey I, Bian H, Cuvelier C, Duncan BN, Folberth G, Horowitz LW, Jonson J, Kaminski JW, Marmer E, Park R, Pringle KJ, Schroeder S, Szopa S, Takemura T, Zeng G, Keating TJ, Zuber A (2008) A multi-model assessment of pollution transport to the Arctic. Atmos Chem Phys 8:5353-5372

Stevenson D et al (2006) Multi-model ensemble simulations of present-day and near-future tropospheric ozone. J Geophys Res 111:D08301

Taylor KE, RJ Stouffer, GA Meehl (2009) A summary of the CMIP5 experiment design. http://www-pcmdi.llnl.gov/

Thompson DWJ, Solomon S (2002) Interpretation of recent southern hemisphere climate change. Science 296. doi:10.1126/science. 1069270

Thomson AM, Calvin KV, Smith SJ, Kyle GP, Volke A, Patel P, Delgado-Arias S, Bond-Lamberty B, Wise MA, Clarke LE et al (2011) RCP4.5: a pathway for stabilization of radiative forcing by 2100. Climatic Change (this issue). doi:10.1007/s10584-011-0151-4

Thornton PE, Lamarque J-F, Rosenbloom NA, Mahowald N (2007) Effects of terrestrial carbon-nitrogen cycle coupling on climate-carbon cycle dynamics. Global Biogeochemical Cycles 21, GB4018, doi:10.1029/2006GB002868

Tie XX, Brasseur GP, Emmons LK et al (2001) Effects of aerosols on tropospheric oxidants: a global model study. J Geophys Res 106:2931-2964

Tie XX, Madronich S, Walters S et al (2005) Assessment of the global impact of aerosols on tropospheric oxidants. J Geophys Res 110. doi:10.1029/2004JD005359

van Vuuren DP, Edmonds J, Kainuma M, Riahi K, Thomson A, Hibbard K, Hurtt GC, Kram T, Krey V, Lamarque J-F, Matsui T, Meinshausen M, Nakicenovic N, Smith SJ, Rose SK (2011a) The representative concentration pathways: an overview. Climatic Change. doi:10.1007/s10584-011-0148-Z

van Vuuren DP, Stehfest E, Den Elzen MGJ, Deetman S, Hof A, Isaac M, Klein Goldewijk K, Kram T, Mendoza Beltran A, Oostenrijk R et al (2011b) RCP2.6: exploring the possibility to keep global mean temperature change below 2 degrees. Climatic Change (this issue). doi:10.1007/s10584-011-0152-3

Young PJ, Arneth A, Schurgers G, Zeng G, Pyle JA (2009) The $\mathrm{CO}_{2}$ inhibition of terrestrial isoprene emission significantly affects future ozone projections. Atmos Chem Phys 9:2793-2803 